\title{
IMAN KRISTEN DAN AKAL BUDI
}

\author{
Hermanto Suanglangi
}

\begin{abstract}
Abstrak
Iman dan akal budi adalah aspek yang tidak Gertentangan, oleh karena iman adalah suatu Keyakinan terfadap sesuatu yang tidak bisa dijangkau oleh rasio (irrasional). Dan akal budi adalah suatu bagian dari manusia yang diciptakan Tufan untuk meneliti, menguraikan, menganafisa segala sesuatu yang bisa dilogikakan. Sefingga pada saat akal Gerfadapan dengan yang bersifat metafisik, maka itu Gukan berarti tidakada, atau bukan kebenaran.
\end{abstract}

\section{Pendahuluan}

Apakah iman bertentangan dengan rasio atau akal budi, ataukah rasio adalah sesuatu yang tidak bersangkut paut dengan iman? Pertanyaan ini pertanyaan klasik di dalam kekristenan, oleh karena pertanyaan ini telah mempengaruhi agama Kristen selama berabad-abad lamanya. Dari pertanyaan di atas muncul dua macam ekstrim yang berbeda, di mana ada yang memandang bahwa orang Kristen harus menekankan iman sebagai satu-satunya pokok yang harus menjadi landasan dalam kehidupan orang Kristen sehingga tidak menekankan rasio. Di lain pihak, ada yang menjadikan rasio sebagai satu-satunya standar segala sesuatu, kalau tidak masuk akal maka itu bukan kebenaran, seperti yang diungkapakan Immanuel Kant "gunakanlah rasiomu setinggi mungkin", bahkan Rene Descartes berkata, "Cogito ergo sum, I tinink therefore I am. I am a thinking being", sehingga segala sesuatu menjadi objek pikiran termasuk Allah, inilah pikiran era Rasionalisme.

Dari kedua opini tersebut di atas, telah membawa kekristenan ke dalam dua model, yaitu:

1. Tidak perlu memakai rasio beriman saja, terima semuanya dengan iman.

2. Menyatakan bahwa akal atau rasio adalah standar dalam meletakkan kebenaran Kristiani.

Jika demikian, maka seorang Kristen yang beriman apakah dia harus membuang rasionya, dan tidak menggunakan akalnya, ataukah, rasio atau akal adalah standar kebenaran Kristiani, jika tidak bisa dimengerti oleh akal, maka itu bukan kebenaran? Pertanyaan-pertanyaan seperti ini telah menggerogoti iman Kristiani selama berabadabad lamanya, bahkan telah membawa iman Kristen keluar dari koridor yang sebenarnya, 
sehingga ketangguhan dan kekokohan iman Kristen tidak kuat lagi oleh karena tidak bisa dipertanggungjawabkan dengan benar. Sehingga pemikir-pemikir tajam seperti Imanuel Kant (1724-1804), Frederich Nietzche (1844-1900), Karl Marx (1818-1803) harus menyangkal iman Kristen karena mereka mengharapkan iman Kristen yang bisa dimengerti dan diterima akal, mereka ini bukanlah orang biasa, mereka adalah orang Kristen, ada yang anak pendeta, bahkan ada yang pernah belajar teologi, kemudian meninggalkan iman Kristen tersebut.

Selama abad pertengahan sampai kira-kira tahun 1700, kebenaran agama Kristen pada umumnya tidak lagi dipertanyakan oleh seluruh umat Kristen. Orang-orang abad pertengahan mungkin mempunyai kesulitan bagaimana menghubungkan iman dan rasio, tetapi pada abad 18 muncul gerakan yang penting, yaitu "Deisme" yang menganjurkan suatu agama yang disederhanakan dan "murni" berdasarkan akal, gerakan ini adalah gerakan yang menyerang agama dari luar. ${ }^{1}$ Dalam keadaan yang demikian, maka Friedrich Schleiermacher (1768-1834) membawa kekristenan dari serangan rasionalisme kepada wilayah perasaan, oleh karena kekristenan pada saat itu diserang oleh kaum rasionalisme demi akal, dan tak lama kemudian, ini berubah menjadi serangan kepada Allah dan agama. ${ }^{2}$

Pertentangan-pertentangan iman dan akal merupakan suatu hal yang krusial dalam iman kekristenan, sehingga sebagai pemimpin gereja, teolog-teolog Kristen, aktivis-aktivis gereja, bahkan para awam sekalipun harus mengerti sinkronisasi dari kedua aspek ini. Lalu bagaimanakah kita mengerti dan mengharmonisasikan kedua aspek ini, yang manakah didahulukan iman atau akal? Itulah sebabnya sehingga dalam tulisan ini, penulis berusaha mengharmonisasikan kedua topik tersebut.

\section{Apakah yang Dimaksud Dengan Iman dan Akal?}

Pertanyaan ini adalah suatu pertanyaan yang sangat penting di dalam mengharmonisasikan iman dan akal, oleh karena tanpa pengertian yang benar, maka tidak mungkin kita bisa mensikronisasikan keduanya.

\section{Iman}

Kata iman dalam bahasa Ibrani, berasal dari kata "Emun", yang berarti kesetiaan, dan kata "Batakh", yang berarti percaya. ${ }^{3}$ Dalam bahasa Yunani, iman berasal dari kata "Pistis", (kata benda), yang berarti kepercayaan, keyakinan, dan iman itu sendiri, dan 
kata "Pisteou" (kata kerja), yang artinya, percaya, meyakini, mengimani.. Dalam istilah bahasa Inggris kata ini mempunyai pengertian yang sama dengan pengertian di atas, yaitu "Faith" berarti kepercayaan, dan keyakinan.

Peter Kreeft dan Ronald K. Tacelli, dalam memberikan definisi iman membagi ke dalam dua bagian.

1. Objek iman, yaitu segala sesuatu yang dipercayai, bagi orang Kristen segala sesuatu yang Allah telah nyatakan dalam Alkitab.

2. Tindakan iman, yaitu bukan hanya percaya tetapi rela mengorbankan diri dalam kepercayaan tersebut. Dalam aspek ini ada empat macam yaitu, (a) Iman emosional, yaitu merasa yakin, percaya atau pasti pada seseorang, (b) Iman intelektual atau kepercayaan, (c) Iman volisional adalah tindakan kehendak, suatu komitmen untuk menaati kehendak Allah, (d) Iman berawal dari pusat keberadaan kita yang penuh rahasia yang oleh kehendak Allah disebut "Hati". ${ }^{6}$

Dari pengertian di atas, maka iman adalah "Kesetiaan", atau "Kepercayaan". Penulis Ibrani memberikan definisi iman, yaitu iman adalah dasar dari segala sesuatu yang kita harapkan dan bukti dari segala sesuatu yang tidak kita lihat (Ibr.11:1). Definisi ini mengandung pengertian bahwa dalam segala hal yang kita harapkan itu ada keyakinan atau kepercayaan yang melandasinya, dan ada keyakinan atau kepercayaan dari segala hal yang tidak kita lihat. Pada saat kita percaya kepada Allah, maka pada saat itu pula kita harus setia, jadi kepercayaan itu bukan hanya bersifat "kognitif" belaka, tetapi harus ada "action" atau tindakan untuk setia kepada Allah. Aspek iman ini adalah aspek yang menyangkut hubungan vertikal, yaitu Tuhan dengan manusia, antara pencipta dengan yang dicipta, sehingga iman adalah dasar atau pokok kepercayaan Kristen, yaitu kepercayaan atau keyakinan terhadap Allah dan wahyu-Nya.

\section{Akal}

Apakah yang dimaksud dengan akal, atau rasio? W.J.S. Poerwadarminta memberikan definisi akal yaitu: alat berpikir; daya pikir (untuk mengerti). ${ }^{7}$ Dalam defenisinya tentang akal, Peter Kreef dan Ronald K. Tacelli membagi akal itu ke dalam dua bagian yang mempunyai pengertian yang berbeda-beda.

1. Objek dari akal. Yaitu segala sesutu yang dapat diketahui oleh pikiran, di mana dalam ral ini melibatkan tiga hal seperti dalam logika Arostoteles klasik, yaitu (a) 
Dimengerti oleh akal tanpa iman, (b) Ditemukan oleh akal sebagai kebenaran, (c) Dibuktikan secara logika tanpa adanya pengaruh dari iman.

2. Tindakan akal. Dalam hal ini melibatkan tiga hal yang terdapat dalam objek akal yaitu memahami, menemukan, dan membuktikan. ${ }^{8}$ Jadi, akal adalah kemampuan yang dimiliki oleh manusia sebagai makhluk ciptaan Tuhan, yang mana manusia terdiri dari pikiran, kehendak, dan perasaan, untuk menyelidiki, menguraikan, meneliti, dan menganalisa segala sesuatu.

\section{Hubungan Sinkronisasi Antara Iman dan Akal}

Merupakan suatu kesulitan pada saat iman dengan akal disatukan, akan tetapi ini merupakan suatu tanggung jawab kekristenan, yaitu bagaimanakah iman dan akal dapat disinkronisasikan? Tujuannya, supaya iman kekristenan tidak rontok oleh perkembangan ilmu pengetahuan, demikian juga oleh kaum intelektual Kristen akan dapat memposisikan sains dalam naungan iman Kristen.

\section{Dimanakah Peranan Iman?}

Seorang filsuf yang hidup pada abab 17-18, yaitu Immanuel Kant, membagi rasio ke dalam tiga bagaian yaitu:

1. Akal murni, yaitu akal yang mempelajari, menganalisa, menguraikan sesuatu hal yang bersifat materi, yaitu segala sesuatu yang masuk akal.

2. Akal praktis, adalah bagian yang menyangkut masalah etika yang tidak bisa diuraikan oleh akal, seperti bagaimanakah manusia harus bermoral, bagaimana manusia harus berkehendak? Pada aspek ini adalar: aspek yang tidak bisa diuraikan dengan akal murni.

3. Akal kritis, yaitu bagian mengenai segala sesuatu di luar diri manusia, seperti bagaimana keberadaan Allah itu? Pada aspek ini juga tidak bisa diuraikan dengan akal murni. Menurut Immanuel Kant, yang paling rendah nilainya adalah akal murni, di mana hanya bisa menguraikan hal-hal yang ada di bawah manusia, halhal yang masuk akal. Etika, atau perilaku manusia, tidak bisa diuraikan dalam laboratorium atau dianalisis dengan akal murni, apalagi tentang hal-hal yang transenden yang berada di luar manusia yaitu Allah. 
view". Di sinilah nyata bahwa iman penting, bahkan Ronald H. Nash berkata bahwa dasar asumsi atau presuposisi itu penting karena sering menjadi cara untuk menentukan metode dan tujuan pemikiran teoritis. ${ }^{10}$

Rasul Paulus berkata bahwa, "Sebab di dalamnya nyata kebenaran Allah, yang bertolak dari iman dan memimpin kepada iman, seperti ada tertulis: orang benar akan hidup oleh iman" (Roma 1:17). Disini nyata, bahwa orang percaya akan hidup oleh iman yang memimpin kepada kebenaran Allah yaitu Injil dan imanlah yang menjadi dasar berpijak yaitu keyakinan kepada kebenaran Allah, sehingga iman adalah hal yang penting dalam sebuah keyakinan.

\section{Dimanakah Peranan Akal?}

Rasio hanya dapat menerima hal-hal yang bisa dilogikakan, sehingga di luar akal maka tidak bisa lagi diterima oleh karena tidak masuk akal, dan itu bukan berarti bahwa hal-hal yang tidak masuk akal tidak ada. Ini semua karena ketidakmampuan akal untuk bisa mengerti segala sesuatu, seperti Allah ada, lalu di manakah peranan akal? Segala sesuatu yang dapat dimengerti, dianalisis, dan dibuktikan oleh akal pikiran manusia, disebut "science" (istilah Inggris). Istilah sains berasal dari bahasa latin, yaitu "Scio", yang berarti I Know, \{saya tahu\}. Jadi segala sesuatu yang saya tahu, yang bisa diuraikan dengan akal saya, maka itu disebut "Science" dalam bahasa Indonesia adalah "sains'. Science inilah yang kemudian disistemkan sehingga disebut sebagai ilmu pengetahuan, seperti: biologi, geologi, antropologi, dll. Hampir semua bidang keilmuan diakhiri dengan kata "logi", yang berasal dari kata "logos" yang artinya ilmu.

Akal adalah salah satu substansi dari diri manusia, karena manusia adalah makluk yang dapat berpikir, berkehendak, dan berperasaan. Aspek rasio ini adalah suatu pemberian Tuhan yang luar biasa kepada manusia untuk kemuliaan Tuhan semata. Itulah sebabnya Firman Tuhan berkata, "Kasihilah Tuhan, Allahmu, dengan segenap hatimu dan dengan segenap jiwamu dan dengan segenap akal budimu. Itulah hukum yang pertama dan terutama" (Mat. 22:37,38).

Dengan apa yang dikatakan Tuhan Yesus di atas, maka prinsipnya adalah bahwa salah satu cara memuliakan Allah adalah memaksimalkan rasio atau akal budi yang telah diberikan Allah bagi kita, untuk mau mengerti wahyu Allah. Sehingga pada saat kita beriman, maka rasio tidak boleh dibuang, tetapi menggunakan akal untuk mau mengerti kehendak Allah melalui firman-Nya. Tetapi jangan memakai rasio sebagai 
standar mutlak kebenaran, oleh karena rasio manusia telah rusak karena dosa dan tidak akan mungkin mencapai kebenaran yang tertinggi tanpa pimpinan dari Roh Kudus.

\section{Keterbatasan Rasio}

Seperti dalam uraian sebelumnya, bahwa rasio adalah aspek dari pribadi manusia yang hanya bisa memahami hal-hal yang ada di bawah manusia dan manusia itu sendiri. Tetapi ketika berhadapan dengan Allah, maka rasio tidak akan mungkin menguraikannya. Akal seperti ini adalah "akal murni" bagi Immanuel Kant, rasiolah yang paling rendah nilainya. Ketika seseorang mendewakan rasio, maka dia sebenarnya berada di dalam kekeliruan yang luar biasa, sebab rasio bukanlah standar dalam menemukan kebenaran.

Ketika sains muncul, bukankah suatu cara manusia untuk berusaha menemukan kebenaran melalui rasio. Akan tetapi jauh sebelum sains ada dan berkembang, sudah ada yang namanya "filsafat", yaitu usaha manusia untuk menemukan kebenaran yang tertinggi. Di mana kata filsafat berasal dari bahasa Yunani, yaitu "filo" dan "sofia". "Filo" berarti cinta, dan "sofia" berarti kebijaksanaan, sehingga filsafat adalah cinta akan kebijaksaan, karena cinta akan kebijaksaan yang tertinggi maka berusaha untuk menemukannya. Di bawah filsafat ada ilmu pengetahuan yaitu "sains" yang berusaha mencari namanya kebenaran. Di atas filsafat ada kebenaran Allah, yaitu kebenaran mutlak, yang dinyatakan melalui wahyu Allah dan ada dalam pribadi Allah itu sendiri. Pada saat kita belajar tentang wahyu Allah, maka itu namanya belajar "teologi", karena teologi adalah pengenalan akan Allah melalui wahyu-Nya.

Dari usaha manusia mencari kebenaran melalui sains, berdasarkan rasio atau akal yang telah dirusak oleh dosa, maka kebenaran manusia adalah kebenaran semu adanya. Di dalamı filsafatlah yang merupakan induk pengetahuan sadar bahwa ada hal-hal yang tidak mungkin dimengerti oleh akal atau rasio manusia, yaitu rasio murni. Itulah sebabnya sehingga di dalam filsafat ada tiga bidang yang penting, yaitu:

1. "Epistimologi", yaitu ilmu tentang ilmu pengetahuan yang menggumuli batasanbatasan ilmu pengetahuan, metode-metode pengetahuan, dst.

2. "Etika", yaitu bidang filsafat yang menggumuli tentang bagaimanakah harus bermoral, bagaimana harus berkehendak, apa standar moral yang tertinggi? dst. 
3. "Metafisik", yaitu bidang filsafat yang menggumuli tentang segala sesuatu yang bersifat non fisik, segala sesuatu yang berada di luar diri manusia, apakah Allah ada, bagaimana keberadaan Allah? dst.

Segala kebenaran yang yang dirumuskan oleh filsafat tidak akan pernah tinggi dari kebenaran Allah, yaitu kebenaran yang dinyatakan dalam Alkitab. Filsafat hanya bisa membuat pertanyaan-pertanyaan tentang segala sesuatu, tetapi tidak mampu memberikan jawaban atas pertanyaan-pertanyaan tersebut, hanya Alkitablah yang mampu menjawab pertanyaan-pertanyaan yang digumuli filsafat. Sehingga teologi adalah suatu keilmuan yang lebih tinggi dari ilmu-ilmu lainnya termasuk filsafat yang merupakan induk pengetahuan, karena teologi adalah suatu studi tentang pengenalan akan Allah sebagai pencipta, dan Dia tidak akan mungkin dapat diteliti, diuraikan, dan dianalisis dalam laboratorium. Berbahagialah orang yang dengan rendah hati mempelajari teologi, dengan penuh penyerahan diri di hadapan Sang Pencipta, yaitu Allah.

Sejarah telah membuktikan bahwa zaman rasionalisme, yaitu zaman yang mendewakan rasio telah gugur karena ketidakmampuan membuktikan ideologi-ideologi mereka. Bahkan kebudayaan besar yang dipelopori oleh Agnostisisme "Primitive Agnosticisme" dari Immanuel Kant, dan "Psiko-analisis" dari Sigmud Freud di Austria (1856-1939), yang menganggap bahwa semua mimpi dalam Alkitab adalah gejala kejiwaan yang tidak sehat. Akhirnya mereka harus mundur dari kemutlakan sains, dan harus menandatangani bahwa ada kuasa supranatural yang tidak dapat dijelaskan oleh rasio manusia, tidak dapat dianalisis oleh sains, dan tidak dapat dibuktikan dalam laboratorium. Ini adalah zaman Post-modernisme sebagai lawan dari zaman Rasionalisme dan Modernisme. ${ }^{11}$

Pada abad ke-19, muncul teori "Evolusi", yang dipelopori oleh Charles Darwin, telah menyesatkan berjuta-juta umat manusia di seluruh dunia, serta telah masuk dan menjadi bahan ajar untuk guru-guru SMA di Indonesia. Tetapi pada abad 20 dan 21 terbukti melalui penelitian para arkeolog, bahwa teori Darwin adalah salah. Pada tahun 2001, ada seratus (100) peneliti ilmuan termasuk Dr. Hendry Schaefer (kandidat penerima hadia nobel. U. of. Georgia Direktur Institut Kimia Kuantum) meragukan teori Darwin. ${ }^{12}$ Sayangnya banyak orang Kristen yang justru lebih percaya kepada teori evolusi, dari pada percaya kepada Alkitab. 
Segala bentuk sains yang menyatakan suatu kebenaran yang berlawanan dengan Alkitab sebagai kebenaran mutlak, terbukti kebenaran sains yang salah karena kebenaran sains adalah bersifat semu adanya, hanya asumsi, dan hipotesa semata. Firman Tuhan berkata, "Sebab apa yang tidak nampak dari pada-Nya, yaitu kekuatan-Nya yang kekal dan keilahian-Nya, dapat nampak kepada pikiran dan karya-Nya sejak dunia diciptakan, sehingga mereka tidak dapat berdalih" (Rm. 1:20).

\section{Penutup}

Iman dan akal budi adalah aspek yang tidak bertentangan, oleh karena iman adalah suatu keyakinan terhadap sesuatu yang tidak bisa dijangkau oleh rasio (irrasional). Dan akal budi adalah suatu bagian dari manusia yang diciptakan Tuhan untuk meneliti, menguraikan, menganalisa segala sesuatu yang bisa dilogikakan. Sehingga pada saat akal berhadapan dengan yang bersifat metafisik, maka itu bukan berarti tidak ada, atau bukan kebenaran. Seperti Allah yang tidak mungkin dimengerti oleh rasio karena rasio terbatas adanya. Disinilah kelemahan sains karena hanya bersifaf hipotesa, asumsi belaka. Oleh karena kebenaran-kebenaran yang dirumuskan dalam sains adalah berisi elemen presaposisi-presaposisi atau asumsi, sehingga tidak ada kemutlakan pada sains.

Iman kekristenan adalah iman rasional, bukan iman yang tidak beralasan atau iman buta-buta, tetapi iman yang didasarkan pada wahyu Allah yang merupakan sumber kebenaran (Alkitab). Sebab segala sesuatu yang dijelaskan oleh Alkitab adalah suatu kebenaran mutlak, yang tidak mungkin dibantah oleh pikiran-pikiran manusia atau sains itu sendiri. Alkitab bukan hanya berisi tentang etika, yaitu bagiamana harus bermoral, bersikap, tetapi juga buku ilmiah yang lebih tinggi dari hasil penelitian para ilmuwan kaliber dunia. Ini terbukti dengan apa yang dikatakan Alkitab tentang penciptaan dunia, di mana hasil dari penelitian sains yang benar, betul-betul mendukung kebenaran Alkitab. Dan akhirnya, "Sebab segala sesuatu adalah dari Dia, dan oleh Dia, dan kepada Dia: Bagi Dialah kemuliaan sampai selama-lamanya!" (Rm. 11:36).

\section{Endnotes:}

' Tony Lane, Runtut Pijar:Sejarah Pemikiran Kristiani (Jakarta: BPK Gunung Mulia, 2001), 196.

${ }^{2}$ Ibid.,

Ensiklopedi Alkitab Masa Kini, Jilid 1, s.v. "Iman"

Barclay M. Newman Jr., Kamus Yunani-Indonesia, (Jakarta: BPK Gunung Mulia, 1997).

John M. Echols, Hasan Shadily, Kamus Inggris-Indcnesia, (Jakarta: PT. Gramedia, 2000), 231. 
${ }^{6}$ Peter Kreeft, Ronald K. Tacelli, Pedoman Apologetika Kristen l, (Bandung: Kalam Hidup, 2000), 37-38.

${ }^{7}$ W. J. S. Poerwadarminta, Kamıs Umum Bahasa Indonesia, (Jakarta: PN Balai Pustaka, 1984), 23.

${ }^{8}$ Peter K. Kreef, Ronald K. Tacelli, Pedoman Apologetika Kristen 1, (Bandung: Kalam Hidup, 2000), 39,40 .

${ }^{9}$ Ronald H. Nash, Iman dan Akal Budi, (Surabaya: Momentum, 2001), 38.

${ }^{10} \mathrm{Ibid}, 39$.

"Stephen Tong, Baptisan dan Karunia Roh Kudus, (Jakarta: Lembaga Reformed Injili Indonesia, 1996), 7.

${ }^{12}$ Jeohn Gwang-Ho, Sains Penciptaan, (Jakarta: Korean Association of Creation Research, 2004), 7.

\section{DAFTAR PUSTAKA}

Alkitab, Jakarta: Lembaga Alkitab Indonesia, 2001

Ensiklopedi Alkitab Masa Kini 1, Jakarta: Yayasan Komunikasi Bina Kasi/ OMF, 2003.

Echols, John M., Shadily, Hasan, Kamus Inggris Indonesia, Jakarta: PT. Gramedia, 2000.

Gwang-Ho, Jeohn, Sains Penciptaan, Jakarta: Kcrean Association of Creatio Research, 2004.

Lane, Tony, Runtut Pijar: Sejarah Pemikiran Kristiani, Jakarta: BPK Gunung Mulia, 2001.

Kreef, Peter, Tacelli, Ronald K., Pedoman Apologetik Kristen 1, Bandung: Kalam Hidup, 2000.

Nash, Ronald H., Konflik Wawasan Dunia, Surabaya: Momentum, 2000.

Newman, Jr., Barclay M., Kamus Yunani-Indonesia, Jakarta: BPK Gunung Mulia, 1997.

Syukur Dister OFM, Nico, Filsafat Agama Kristen, Jakarta: BPK Gunung Mulia-Kanisius Yogyakarta, 1985.

Tong, Stephen, Baptisan dan Karunia Roh Kudus, Jakarta: Lembaga Reformed Injili Indonesia, 1996. 1995. Iman, Rasio dan Kebenaran, Jakarta: Lembaga Reformed Injili Indonesia, 